\title{
Upaya Meningkatkan Kualitas Produk Bakso Berdasarkan Model Kano di CV Mett Ball Foods
}

\author{
Irman Maulana ${ }^{1}$, Dian Jingga Permana ${ }^{2}$ \\ ${ }^{1,2}$ Program Studi Teknik Industri, Universitas Indraprasta PGRI, Jakarta \\ ${ }^{1}$ maulana.irman@gmail.com, ${ }^{2}$ dianjpermana@gmail.com
}

\begin{abstract}
Abstrak
Peluang bisnis pengolahan makanan (bakso) begitu besar, ketatnya persaingan antar para pemain dalam merebut pelanggan mengharuskan para pemainya dapat meningkatkan kualitas produknya berdasarkan persepsi pelanggan. penelitian ini bertujuan untuk meningkatkan kualitas produk bakso berdasarkan model Kanometode. Metode yang digunakan dalam penelitian ini menggunakan metode atau model Kano yang dikombinasikan dengan delapan dimensi kualitas TQM atau dimensi Garvin 1987 untuk kategori barang. Hasil penelitian menunjukan terdapat enam atribut tergolong kategori Must-be, lima atribut tergolong kategori One-dimensional, tiga atribut tergolong kategori Attractive dan 16 atribut tergolong kategori Inddiffrent.Prioritas perbaikan kualitas yang harus dilakukan guna meningkat kepuasan pelanggan terdapat pada katergori One-dimensionalpada Atribut B12, B14, B17, B21 dan Attractive pada Atribut B1, B2 dan B19.
\end{abstract}

Kata kunci : Kepuasan Pelanggan, Model Kano, Dimensi kualitas(TQM), Kualitas

\begin{abstract}
The opportunity for processing food (Bakso) is so large, the intense competition between players in seizing customers requires that the customers can improve the quality of their products based on customer perceptions. This study aims to improve the quality of meatball products based on the Kano model method. The method used in this study uses the Kano method or model combined with eight dimensions of TQM quality or Garvin 1987 dimensions for the goods category. The results showed that there were six attributes belonging to the Must-be category, five attributes belonging to the Onedimensional category, three attributes belonging to the Attractive category and 16 attributes belonging to the Inddiffrent category. The quality improvement priorities that must be made in order to increase customer satisfaction are found in the One-dimensional category of B12, B14, B17, B21 and Attractive Attributes on Attributes B1, B2 and B19.
\end{abstract}

Key words : Customer Satisfaction, Canoe Model, Dimensions of quality (TQM)

\section{PENDAHULUAN}

CV Mett Ball Foods sebagai salah satu produsen yang memproduksi bakso di wilayah bekasi,menjaga kualitas produk dan terus berupaya meningkatkan kepuasan pelangganmenjadi prioritas utama yang harus dilakukan untuk tetap bertahan ditengah persaingan yang semakin sengit.Bakso merupakan produk olahan daging sapi yang mudah ditemui, memiliki banyak pengemar dan sangat populer di Indonesia [1]. Bakso juga dapat terbuat dari olahan daging ikan yang disebut bakso ikan manan ini banyak disukai dan cukup populer karena dalam penyajiannya tidak hanya dapat direbus namun bisa digoreng dan dibakar [2].Peluang bisnis baksobegitu besar karena pasar telah menerima produk ini, semakin besar peluang dalam bisnis ini maka akan semakin ketatnya persaingan antar para pemain dalam merebut pelanggan. 
Kepuasan pelanggan menjadi salah satu strategi perusahaan yang harus ditingkatkan, yaitu dengan menjaga kualitas produknya.

Kepuasan pelanggan akan mempengaruhi keputusan konsumen dalam membeli suatu produk, tidak hanya faktor kualitas produk saja namun keputusan membeli pun di pengaruhi oleh faktor pendukung yang disediakan oleh para produsen. Keputusan konsumen dalam membeli produk makanan olahanataupunfrozen food di pengarui oleh banyak hal, diantaranya tekait sejauh mana konsumen mengetahui dan mengenal informasi produk secara lengkap, Kemasan yang berbeda dan memiliki daya tarik tersendiri akan menambah kesan terhadap ciri khas produktersebut ataupun rekomendasi dari pengguna lainnyaterkait apa yang telah meraka rasakan[3]. Produk yang memiliki daya saing tentunya produk yang sesuai dengan kebutuhan dan keinginan pelanggan, kepuasan akan kualitas suatu produk dapat meningkatkan loyalitas[4]. Perusahaan yang terus melakukan inovasi produknya dapat menguragi kejenuhan pasar dan meningkatkan loyalitas pelanggan [5]. Di sisi lain, produk makanan yang berkualitas juga harus memberikan rasa aman bagi para penggunanya, namun pada kenyataannya masih saja ada produsen yang tak bertanggung jawab memproduksi produk makanan olahan (bakso) dengan menggunaan bahan berbahaya seperti boraks dan formalin. Biasanya para produsen nakal menggunakan boraks agar makanan menjadi lebih menarik, kenyal dan tahan lama [6]. Penjual bakso keliing pun terkadang menggunakan bahan ini meskipun mereka tahu bahwa bahan itu berbahaya dan penggunaan bahan ini tidak hanya pada produk bakso saja namun banyak ditemukan pada makanan jajanan anak sekolah [7].

Kepuasan dan loyalitas pelanggan sangat di pengaruhi oleh produk yang berkualitas, sedangakan persepsi akan produk yang berkualitas ditentukan oleh pelanggan. Melalui peningkatan kualitas produk sesuai harapan dan kebutuhan pelanggan akan dapat meningkatkan kepuasan pelanggan.Ada delapan dimensi dasar kualitas produk yang terdiri dari : 1). Kinerja utama, 2). Fitur, 3). Daya tahan, 4). Kesesuaian, 5). Daya tahan, 6). Kemampuan pelayanan, 7). Tampilan, 8). Kualitas yang dirasakan [8]. Metode kano digunakan untuk mengetahui kebutuhan pelanggan apa saja yang dapat meningkatkan kepuasan pelanggan atau tidak memberikan dampak terhadap kepuasan pelanggan tersebut [9]. Metode Kano digunakan pada proses perancangan pengembangan produk baru sesuai kebutuhan pelanggan [10]. Metode Kano dapat digunakan untuk menetukan apakah atribut - atribut dalam dimensi kualitas dapat meningkatkan kepuasan pelanggan.Berdasarkan fenomena dan permasalahan yang terjadi bisnis pengolahan makanan(bakso) tersebut maka penelitian ini bertujuan untuk meningkatkan kualitas produk bakso berdasarkan model Kano.

\section{METODE PENELITIAN}

Dalam penelitiaan ini, metode yang digunakan adalah dengan menggunakaan metode atau model Kano yang diciptakan oleh Prof Nariaki Kano (1984), penentuan atribut kualitas dalam kuesioner berbasis kriteria dimensi kualitas TQM atau yang sering dikenal dengan delapan dimensi Garvin 1987 untuk kategori barang. Metode kano digunakan untuk mengetahui kebutuhan pelanggan apa saja yang dapat meningkatkan kepuasan pelanggan atau tidak memberikan dampak terhadap kepuasan pelanggan tersebut [11]. Teori model kano dapat digunakan dalam memahami hubungan tentang atribut kualitas dan kepuasan pelanggan pada tingkat atribut berdasarkan perspektif pelanggan [12]. 


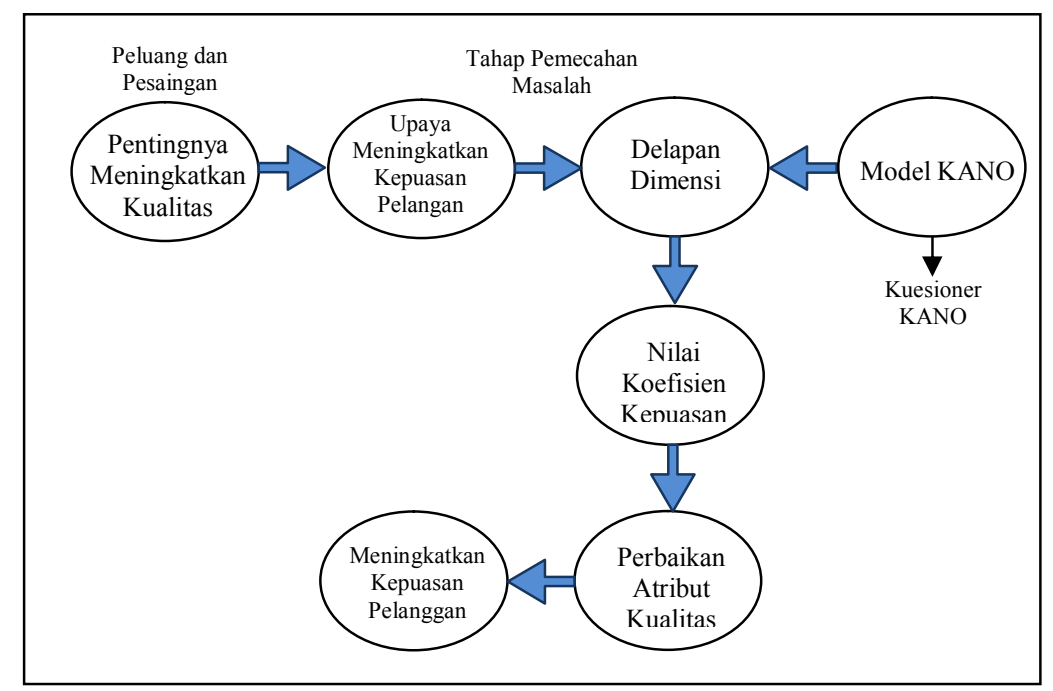

Gambar 1. Alur Pikir Penelitian

Berdasarkan Gambar 1, Alur pikir penelitian ini terdiri dari lima tahap prosesyang terdiri dari :

1. Tahap In-put : Menganalisa permasalah terhadap fenomena yang terjadi ketika perusahaan berada dalam bisnis pengolahan makanan (bakso).

2. Tahap Proses : Menentukan pemecahan masalah untuk meningkatkan kepuasan pelanggan dan kualitas produk dengan menggunakan model Kano berbasis delapan dimensi kualitas (Gravin), pengolahan data dalam penelitian ini berdasarkan teori Walden (1993) dengan menggunakan tabel evaluasi kano.

3. Tahap Output : Hasil pengolahan data yang di dapat berupa nilai koefisien kepuasan pelanggan berdasarkan model kano.

4. Tahap Outcame : Rekomendasi perbaikan atribut kualitas berdasarkan model kano sehingga perusahaan dapat memperbaiki kualitas produk makanan olahan (bakso

5. Tahap Benefit : Upaya perbaikan akan kualitas produk diharapakan dapat meningkatkan kepuasan pelanggan

\section{HASIL DAN PEMBAHASAN}

\section{A. Penentuan Kriteria dan Sub kriteria Kuesioner}

Kriteria dan sub kriteria kuesioner merupakan dimensi kualitas berdasarkan teori TQM yang di kombinasikan dengan hasil pengamatan tahap awal terhadap obyek, adapun kreteria dan sub kriteria yang terdapat dalam kuesioner terdapat pada Tabel 1. dibawah ini :

Tabel 1.Daftar Kriteria dan Sub Kriteria kuesioner

\begin{tabular}{|c|c|c|c|}
\hline No & Kriteria & Butir & Sub Kriteria \\
\hline 1 & Kinerja Produk & $\begin{array}{l}1 \\
2 \\
3\end{array}$ & $\begin{array}{l}\text { Produk ini memiliki Harga terjangkau namun kualitas premium } \\
\text { Produk ini berkualitas, lezat dan enak } \\
\text { Produk ini tidak mengandung bahan berbahaya atau Pengawet (Boraks) }\end{array}$ \\
\hline 2 & Fitur & $\begin{array}{l}4 \\
5 \\
6 \\
7 \\
8 \\
9\end{array}$ & $\begin{array}{l}\text { Di kemasanya terdapat keterangan Halal dari MUI } \\
\text { Di kemasanya terdapat keterangan Izin dari BPOM } \\
\text { Di kemasanya terdapat tanggal kadarluarsa } \\
\text { Di kemasanya terdapat tanggal produksi } \\
\text { Di kemasanya terdapat nama perusahaan } \\
\text { Di kemasanya terdapat logo Standarisasi mutu (SNI) }\end{array}$ \\
\hline
\end{tabular}




\begin{tabular}{cccl}
\hline No & Kriteria & & \\
\hline & & 10 & Di kemasanya terdapat keterangan saran penyimpan produk \\
& & 11 & Di kemasanya terdapat keterangan tentang komposisi produk \\
\hline 3 & Kehandalan & 12 & Produk ini memiliki Tingkat kekenyalan yang baik \\
& & 13 & Produk ini memiliki Tingkat ke-empuk (lembut) yang baik \\
& & 14 & Produk ini terbuat dari daging sapi yang berkualitas baik \\
& & 15 & Produk ini memiliki Kandungan gizi yang baik \\
& & 16 & Produk ini memiliki varian rasa produk yang berbeda \\
& & 17 & Produk ini memiliki Kemasan produk bakso yang higenis \\
\hline 4 & Kesesuaian & 18 & Produk ini Jumlah atau isi sesuai dengan yang tertera di kemasan \\
& & 19 & Produk ini Memiliki cita rasa yang enak sesuai yang tertera di kemasan \\
\hline 5 & Daya Tahan & 20 & Produk ini tidak mudah rusak / berubah (basi) \\
& & 21 & Produk ini tidak harus disimpan dalam suhu dingin \\
& & 22 & Memiliki kemasan tidak mudah rusak \\
\hline 6 & Kemampuan & 23 & Produk ini tersedia di pasar Tradisional \\
& Pelayanan & 24 & Produk ini tersedia di pasar Modern \\
& & 25 & Produk ini Kemudahan dalam pengaduan keluhan Pelanggan \\
\hline 7 & Aestetika & 26 & Produk ini memiliki bentuk bakso yang bulat sempurna \\
& & 27 & Produk ini memiliki Tampilan Kemasan yang menarik \\
& & 28 & Produk ini memiliki warna bakso yang menarik dan baik \\
\hline 8 & Kesan Kualitas & 29 & Perusahaan / Merek dagang ini sudah dikenal banyak masyarakat \\
& (Persepsi) & 30 & Produk ini diproduksi mengunakan teknologi mesin yang modern \\
\hline
\end{tabular}

\section{B. Karakteristik Responden}

Karakteristik responden menjadi faktor pendukung apakah data dari proses pengambilan tersebut dapat mewakili dari populasi pengguna produk bakso dari CV. Meat Ball Foods, berdasarkan hasil pengumpulan data yang dilakukan kepada 60 orang responden maka dapat dikatakan bahwa data tersebut telah di isi oleh pelanggan yang mengenali dan menggunakan produk tersebut seperti yang terlihat dalam Tabel di bawah ini

Tabel 2. Karakteristik Responden

\begin{tabular}{|c|c|c|}
\hline No & Karakteristik Responden & Keterangan \\
\hline 1 & Jenis Kelamin Responden & $70 \%$ wanita dan $30 \%$ laki - laki \\
\hline 2 & Berusia Responden & $\begin{array}{l}65 \% \text { berusia } 31-40 \text { Tahun, } 20 \% \text { berusia } 41-50 \\
\text { Tahun dan } 15 \% \text { lainnya }\end{array}$ \\
\hline 3 & $\begin{array}{l}\text { Latar belakang pendidikan } \\
\text { Responden }\end{array}$ & $\begin{array}{l}50 \% \text { Setingkat SMA, } 30 \% \text { seringkat } \mathrm{d} 3 / \mathrm{S} 1 \text { dan } \\
20 \% \text { lainnya }\end{array}$ \\
\hline 4 & Responden Berprofesi sebagai & $\begin{array}{l}57 \% \text { Ibu Rumah Tangga, 23\% Pegawai swasta, } \\
\text { 20\% lainnya }\end{array}$ \\
\hline 5 & $\begin{array}{l}\text { Tingkat pendapatan keluarga } \\
\text { Responden }\end{array}$ & $\begin{array}{l}40 \% 2,1-3 \text { Juta Perbulan, } 35 \% 3,1 \text { - } 5 \text { Juta } \\
\text { Perbulan, 25\% lainnya }\end{array}$ \\
\hline 6 & $\begin{array}{l}\text { Lamanya Responden mengenal } \\
\text { produk ini }\end{array}$ & $\begin{array}{l}\text { 46\% Lebih dari } 1 \text { Tahun, 38\% Lebih dari } 2 \text { Tahun } \\
\text { dan } 16 \% \text { lainnya }\end{array}$ \\
\hline 7 & $\begin{array}{l}\text { Frekuensi Responden mengkomsumsi } \\
\text { Bakso }\end{array}$ & $67 \%$ Sering, $25 \%$ jarang, dan $18 \%$ lainnya \\
\hline 8 & Tempat Responden membeli produk & $64 \%$ Outlet Rumahan dan $36 \%$ teman \\
\hline
\end{tabular}

\section{Uji Validitas}

Kuesioner Kepuasan Pelanggan terdiri dari 30 butir pertanyaan yang diberikan kepada 20 responden, Uji coba awal untuk mengetahui apakah butir pertanya memiliki tingkat Validitas yang baikdengan kiteria pengujian nilai $r_{\text {hitung }}>r_{\text {tabel. }}$. Secara keseluruhan hasil perhitungan nilai validitas dinyatakan valid. 
Jurnal Optimasi Teknik Industri (2019) Vol. 1 No. 1, 25-33

Tabel 4. Hasil Uji Validtas

\begin{tabular}{cccc}
\hline No & r Hitung & r Tabel & ket \\
\hline B1 & 0.904 & 0.444 & Valid \\
\hline B2 & 0.943 & 0.444 & Valid \\
\hline B3 & 0.940 & 0.444 & Valid \\
\hline B4 & 0.934 & 0.444 & Valid \\
\hline B5 & 0.947 & 0.444 & Valid \\
\hline B6 & 0.941 & 0.444 & Valid \\
\hline B7 & 0.941 & 0.444 & Valid \\
\hline B8 & 0.936 & 0.444 & Valid \\
\hline B9 & 0.882 & 0.444 & Valid \\
\hline B10 & 0.830 & 0.444 & Valid \\
\hline B11 & 0.957 & 0.444 & Valid \\
\hline B12 & 0.946 & 0.444 & Valid \\
\hline B13 & 0.957 & 0.444 & Valid \\
\hline B14 & 0.945 & 0.444 & Valid \\
\hline B15 & 0.955 & 0.444 & Valid \\
\hline B16 & 0.957 & 0.444 & Valid \\
\hline B17 & 0.943 & 0.444 & Valid \\
\hline B18 & 0.932 & 0.444 & Valid \\
\hline B19 & 0.947 & 0.444 & Valid \\
\hline B20 & 0.956 & 0.444 & Valid \\
\hline B21 & 0.951 & 0.444 & Valid \\
\hline B22 & 0.903 & 0.444 & Valid \\
\hline B23 & 0.909 & 0.444 & Valid \\
\hline B24 & 0.894 & 0.444 & Valid \\
\hline B25 & 0.958 & 0.444 & Valid \\
\hline B26 & 0.885 & 0.444 & Valid \\
\hline B27 & 0.862 & 0.444 & Valid \\
\hline B28 & 0.947 & 0.444 & Valid \\
\hline B30 & 0.961 & 0.444 & Valid \\
\hline & 0.869 & 0.444 & Valid \\
\hline
\end{tabular}

\section{Uji Realibilitas}

UjiReliabilitas dilakukan untuk menentukan tingkat kepercayaan atau konsistensi suatu tes yang telah diujikan, adapun nilai Realibilitas tergolong sangat kuat dengan nilai koefisien realibitas sebesar 0,938 seperti yang tersaji pada tabel dibawah ini.

Tabel 5. Hasil Uji Realibilitas

\begin{tabular}{llcc}
\hline & \multicolumn{3}{c}{ Case Processing Summary } \\
\hline & & $\mathrm{N}$ & $\%$ \\
\hline \multirow{3}{*}{ Cases } & Valid & 20 & 100.0 \\
\cline { 2 - 4 } & Excluded $^{\mathrm{a}}$ & 0 & .0 \\
\cline { 2 - 4 } & Total & 20 & 100.0 \\
\hline
\end{tabular}

a. Listwise deletion based on all variables in the procedure.

$\underline{\text { Reliability Statistics }}$

\begin{tabular}{cc}
\hline Cronbach's Alpha & N of Items \\
.938 & 30 \\
\hline
\end{tabular}

\section{E. Penentuan Atribut Kualitas Berdasarkan Model Kano}

Setelah menyebarkan kuesioner Kano kepada 40 responden maka tahap selanjutnya adalah melakukan pengolahan data tingkat kepentingan preferensi pelanggan berdasarkan model Kano, adapun secara keseluruhan hasil perhitungan evaluasi model Kano tersaji pada tabel dibawah ini : 
Jurnal Optimasi Teknik Industri (2019) Vol. 1 No. 1, 25-33

Tabel 6. Hasil Evaluasi Model Kano

\begin{tabular}{ccccccccc}
\hline Butir & O & A & M & I & R & Q & Total & Grade \\
\hline B1 & 11 & 14 & 1 & 2 & 12 & 0 & 40 & A \\
\hline B2 & 16 & 17 & 1 & 4 & 2 & 0 & 40 & A \\
\hline B3 & 0 & 0 & 21 & 17 & 0 & 2 & 40 & M \\
\hline B4 & 15 & 0 & 21 & 3 & 0 & 1 & 40 & M \\
\hline B5 & 12 & 0 & 18 & 10 & 0 & 0 & 40 & M \\
\hline B6 & 8 & 1 & 25 & 5 & 1 & 0 & 40 & M \\
\hline B7 & 16 & 0 & 3 & 18 & 2 & 1 & 40 & I \\
\hline B8 & 11 & 2 & 0 & 18 & 8 & 1 & 40 & I \\
\hline B9 & 13 & 0 & 0 & 16 & 11 & 0 & 40 & I \\
\hline B10 & 5 & 0 & 0 & 33 & 0 & 2 & 40 & I \\
\hline B11 & 10 & 0 & 0 & 18 & 12 & 0 & 40 & I \\
\hline B12 & 36 & 0 & 0 & 4 & 0 & 0 & 40 & O \\
\hline B13 & 13 & 1 & 0 & 22 & 1 & 3 & 40 & I \\
\hline B14 & 16 & 1 & 6 & 3 & 11 & 3 & 40 & O \\
\hline B15 & 7 & 0 & 0 & 19 & 0 & 14 & 40 & I \\
\hline B16 & 14 & 0 & 0 & 19 & 0 & 7 & 40 & I \\
\hline B17 & 17 & 0 & 7 & 5 & 0 & 11 & 40 & O \\
\hline B18 & 4 & 0 & 14 & 19 & 3 & 0 & 40 & I \\
\hline B19 & 0 & 21 & 0 & 7 & 0 & 12 & 40 & A \\
\hline B20 & 0 & 0 & 35 & 5 & 0 & 0 & 40 & M \\
\hline B21 & 35 & 0 & 0 & 5 & 0 & 0 & 40 & O \\
\hline B22 & 0 & 4 & 1 & 35 & 0 & 0 & 40 & I \\
\hline B23 & 31 & 0 & 0 & 9 & 0 & 0 & 40 & O \\
\hline B24 & 0 & 1 & 6 & 28 & 5 & 0 & 40 & I \\
\hline B25 & 1 & 4 & 6 & 14 & 4 & 11 & 40 & I \\
\hline B26 & 3 & 1 & 12 & 24 & 0 & 0 & 40 & I \\
\hline B27 & 1 & 1 & 17 & 21 & 0 & 0 & 40 & I \\
\hline B28 & 2 & 0 & 0 & 4 & 33 & 1 & 40 & R \\
\hline B29 & 7 & 0 & 7 & 26 & 0 & 0 & 40 & I \\
\hline B30 & 0 & 10 & 0 & 21 & 4 & 5 & 40 & I \\
\hline
\end{tabular}

\section{F. Penentuan Nilai Koefisien Kepuasan Pelanggan}

Nilai koefisien kepuasan pelanggan digunakan untuk menentukan seberapa kuat suatu fitur produk dapat mempengaruhi kepuasan dan ketidakpuasan pelanggan terhadap kualitas, adapun secara keseluruhanhasil perhitungan nilai koefisien tersaji pada tabel di bawah ini :

Tabel 7.Nilai Koefisien Kepuasan Pelanggan

\begin{tabular}{ccc}
\hline Butir & Better & Worse \\
\hline B1 & 0.893 & 0.429 \\
\hline B2 & 0.868 & 0.447 \\
\hline B3 & 0.000 & 0.553 \\
\hline B4 & 0.385 & 0.923 \\
\hline B5 & 0.300 & 0.750 \\
\hline B6 & 0.231 & 0.846 \\
\hline B7 & 0.432 & 0.514 \\
\hline B8 & 0.419 & 0.355 \\
\hline B9 & 0.448 & 0.448 \\
\hline B10 & 0.132 & 0.132 \\
\hline
\end{tabular}


Jurnal Optimasi Teknik Industri (2019) Vol. 1 No. 1, 25-33

\begin{tabular}{ccc}
\hline Butir & Better & Worse \\
\hline B11 & 0.357 & 0.357 \\
\hline B12 & 0.900 & 0.900 \\
\hline B13 & 0.389 & 0.361 \\
\hline B14 & 0.654 & 0.846 \\
\hline B15 & 0.269 & 0.269 \\
\hline B16 & 0.424 & 0.424 \\
\hline B17 & 0.586 & 0.828 \\
\hline B18 & 0.108 & 0.486 \\
\hline B19 & 0.750 & 0.000 \\
\hline B20 & 0.000 & 0.875 \\
\hline B21 & 0.875 & 0.875 \\
\hline B22 & 0.100 & 0.025 \\
\hline B23 & 0.775 & 0.775 \\
\hline B24 & 0.029 & 0.171 \\
\hline B25 & 0.200 & 0.280 \\
\hline B26 & 0.100 & 0.375 \\
\hline B27 & 0.050 & 0.450 \\
\hline B28 & 0.333 & 0.333 \\
\hline B29 & 0.175 & 0.350 \\
\hline B30 & 0.323 & 0.000 \\
\hline
\end{tabular}

Setelah melakukan perhitungan nilai koefisien kepuasan pelanggan, maka tahap selanjutnya adalah menentukan langkah perbaikan agar dapat terwujudnya tingkat kepuasan pelanggan pada setiap atribut dimensi kualitas melalui proses peletakkan nilai - nilai koefisien tersebut kedalam Matriks Diagram Kartesius seperti yang terlihat pada Gambar di bawah ini.

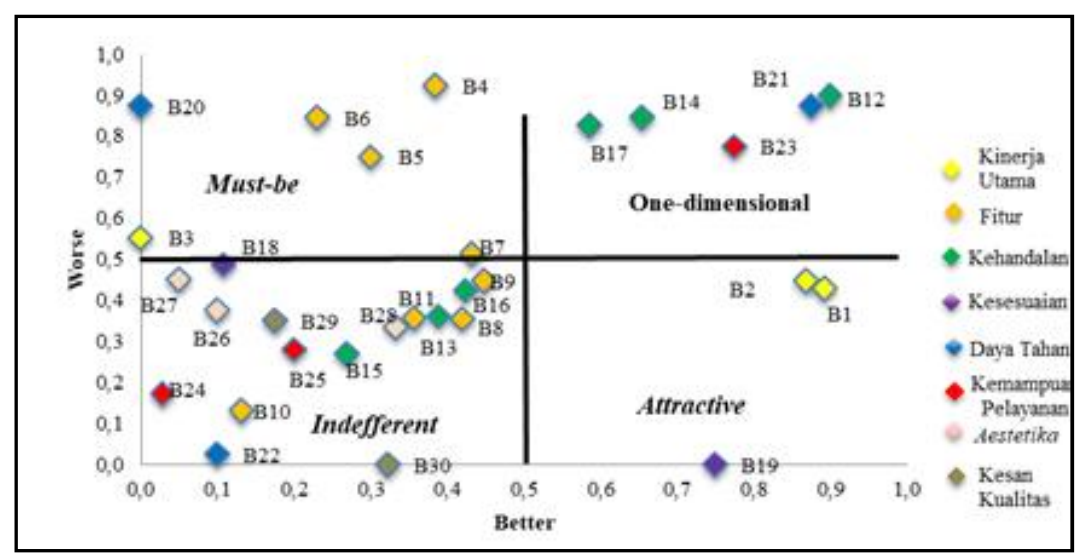

Gambar 2. Diagram Kartesius Koefisien Kepuasan Pelanggan

Berdasarkan Gambar diatas maka kategori nilai koefisienpelanggan terbagi menjadi empat kuadran, yaitu :

- Kuadran I : Terdapat 6 atribut tergolong kategoriMust-be, adapun perbaikan pada kategori ini tidak akan berdampak kepada peningkatan kepuasan pelanggan, namun bila tindak ada akan membuat pelangan akan kecewa.

- Kuadran II : Terdapat 5 atribut tergolongkategoriOne-dimensional, adapun perbaikan pada kategori ini akan berdampak kepada peningkatan kepuasan pelanggan.

- Kuadran III : Terdapat 3 atribut tergolongkategori Attractive, adapun perbaikan pada kategori ini akan berdampak kepada peningkatan kepuasan pelanggan. 
- Kuadran IV : Terdapat 16 tergolongkategoriInddiffrent, adapun perbaikan pada kategori ini akan berdampak kepada penilaian pelanggan baik dan buruk suatu produk.

Prioritas perbaikan kualitas yang harus dilakukan guna meningkat kepuasan pelanggan terdapat pada katergori One-dimensionalyaitu Atribut B12, B14, B17, B21 dankatergori Attractiveyaitu Atribut B1, B2 dan B19, Peningkatkan kinerja pada kategori Must-be menjadi tidak produktif kerana pelanggan sudah berada pada tingkat yang memuaskan dibandingkan dengan peningkatan kinerja pada kategori One-dimensional atau Attractive [13].

\section{SIMPULAN DAN SARAN}

Kesimpulan dalam penelitian inimenghasilan usulan prioritas perbaikan kinerja kualitas atribut berdasarkan metode kano padakatergori One-dimensionaluntukatribut B12, B14, B17, B21 dan pada katergori Attractiveuntuk atribut B1, B2 dan katergori Attractive pada Atribut B1, B2 dan B19. Hasil temuan ini diharapkan dapat menjadi bahan pertimbangan bagi perusahaan dalam terus meningkatkan kualitas, penelitian lebih lanjut dapat dikembangkan pada konsumen yang berada di wilayah lain.

\section{UCAPAN TERIAMA KASIH}

Dalam kesempatan ini, peneliti ingin mengucapakan terima kasih pada pimpinan dan karyawan CV Mett Ball Foods yang telah mendukung dan membantu memberikan informasi terkait proses bisnis pengolahan makanan (bakso).

\section{DAFTAR PUSTAKA}

[1] Handayani, T., \& Wahyudi, I. (2018). Uji Ph, Kadar Air Dan Mutu Mikrobiologi Bakso Di Kota Padang. Jurnal Katalisator, 3(1), 61-70.

[2] Nurhuda, H. S., \& Rochima, E. (2017). Penambahan Tepung Karaginan Terhadap Tingkat Kesukaan Bakso Ikan Manyung. Jurnal Perikanan Kelautan, 8(1).

[3] Santoso, I., Mustaniroh, S. A., \& Pranowo, D. (2018). Keakraban Produk dan Minat Beli Frozen Food: Peran Pengetahuan Produk, Kemasan, dan Lingkungan Sosial. Jurnal Ilmu Keluarga \& Konsumen, 11(2), 133-144.

[4] Khaeruroh, N., Hasiholan, L. B., \& Mukeri, M. (2018). The Influence Of The Quality Of The Produk, Service Quality, Trust To The Customer Loyalty To The Customer Satisfaction As A Variable Intervening (Study In Pt Morich Indo Fashion Ungaran). Journal of Management, 4(4).

[5] Alimudin, A., \& Yoga, H. (2015). Strategi meningkatkan loyalitas pelanggan pada usaha kecil produk makanan ringan di surabaya. Sustainable Competitive Advantage (SCA), 5(1).

[6] Rosyidah, A., Purwanti, E., Hartanto, D., Murwani, I. K., Prasetyoko, D., \& Ediati, R. (2017). Penataan PKL Bebas Boraks dan Formalin Menuju Produk Unggulan Sehat dan Higienis. Qardhul hasan: media pengabdian kepada masyarakat, 3(2), 86-98.

[7] Santi, A. U. P. (2018). Analisis Kandungan Zat Pengawet Boraks Pada Jajanan Sekolah Di Sdn Serua Indah 1 Kota Ciputat. Jurnal Holistika, 1(1).

[8] Garvin, D. A., \& Quality, W. D. P. (1984). Really Mean. Sloan management review, 25.

[9] Mastrisiswadi, H., \& Herianto, H. (2017). Analisis kebutuhan robot rehabilitasi pasien pasca stroke dengan menggunakan metode Kano. Jurnal Ilmiah Teknik Industri, 15(2), 151-156.

[10] Sidiq, R., \& Purnomo, H. (2017). Desain Spatula Ergonomis Menggunakan Pendekatan Model Kano. Jurnal Teknoin, 22(7).

[11] Mastrisiswadi, H., \& Herianto, H. (2017). Analisis kebutuhan robot rehabilitasi pasien pasca stroke dengan menggunakan metode Kano. Jurnal Ilmiah Teknik Industri, 15(2), 151-156. 
Jurnal Optimasi Teknik Industri (2019) Vol. 1 No. 1, 25-33

[12] Witell, L., Löfgren, M., \& Dahlgaard, J. J. (2013). Theory of attractive quality and the Kano methodology-the past, the present, and the future. Total Quality Management \& Business Excellence, 24(11-12), 1241-1252.

[13] Berger, C. (1993). Kano's methods for understanding customer-defined quality. Center for quality management journal, 2(4), 3-36. 